\title{
Viola Bernard and the case study of race in post-war America
}

\author{
Joy Damousi
}

The writings and political activism of Viola Bernard, a psychoanalyst of German-Jewish background who practised in New York during the twentieth century, provide a further prism through which to consider the genre of the case study, as well as broader questions concerning intersections between culture, politics and the discourses of psychiatry and psychoanalysis. A resilient political and social activist, Bernard was committed to many progressive causes. These included support of trade union activism, black rights, women's rights and civil liberties. Throughout her career she believed that psychiatric and psychoanalytic techniques could be deployed to assist in achieving wider social reforms. She became active in assisting European refugees from German National Socialism, and in 1939 travelled to Europe to examine the plight of refugee children in Britain and France. Merging her commitment to psychoanalysis and psychiatry with social causes, Bernard's study of race - in many of its facets - increasingly took a political form.

Bernard's campaign on the issue of race forms the basis of this chapter. Such a focus deviates from the approach taken in the preceding chapters of this volume. Here the theme is a case study 'in formation' rather than a development or variation in the tradition of the case study genre. The context is the highly charged political environment in the USA from the 1940 s to the $1960 \mathrm{~s}$. The issue is that of race and the expert field of psychoanalysis: specifically, the development of a profoundly transformative case study narrative about black subjects within this field - and within post-war American politics and society. This chapter demonstrates the difficulties of constructing case studies, or at least advocating them, at certain historic moments that are characterised by political tensions, social unrest, distrust and paranoia. It also highlights the challenges of documenting case histories. When considering the history of case studies in this post-war context, the materials available are necessarily fragmented and disparate. At the time, the discourse of race and psychiatry was emerging in new ways through a range of sources. This chapter draws on a wide variety of sources, including public discussions as 
these were reflected in the press; specialised talks within the professions of psychiatry and psychoanalysis; and Bernard's personal correspondence. These materials all pertain to an evolving narrative, the writers responding to political and social events as they unfolded.

As the civil rights movement in the USA gained momentum from the $1940 \mathrm{~s}$, Bernard was ahead of her time in advocating the urgent need to train more African-Americans for entry into the profession of psychiatry. She believed that African-American people should have access to the best psychiatric assistance available. But for Bernard it was not a matter of merely adding to the field more trained psychiatrists from an AfricanAmerican background. Her advocacy also involved using her extensive contacts and influence to interrogate the nature of psychiatry and to investigate how the 'problem' of cultural difference was addressed in American psychiatric and psychoanalytic training and practice. Bernard's civil rights campaigning was never simply of academic or theoretical importance. Rather, it took place in political arenas, and involved mobilising fellow advocates as well as expert knowledge on key issues, with the aim of making a profound difference to the lives and rights of black and white Americans.

Bernard's activism points to the ways in which her exploration of the 'case' of the 'Negro' - as African-Americans were then termed - became framed by cultural and political considerations. ${ }^{1}$ This was especially notable in the position she took concerning the civil liberties of AfricanAmericans, and in her attempts to promote them inside the medical profession, in psychiatry and in the wider society, such that she became a leading supporter of black civil rights in post-war America.

Although this chapter is centred on the emerging case study of race and its intersection with medicine during the post-war period, Bernard's work on cases of 'sexual deviance' links her practice and ethos as a psychoanalyst to earlier chapters in this volume. Many of Bernard's patients were middle-class women who struggled with their sexual identity and subjectivity when they deviated from the 'norm' of heterosexuality. Bernard offered psychoanalytic treatments that resisted labelling these women as deviant. As such, Bernard was progressive for her era insofar as she was reluctant to label and dismiss homosexual and bisexual behaviours, at a time when sexual behaviours other than heterosexual were considered abnormal, and were, indeed, often illegal. ${ }^{2}$ This defiance of contemporary practices and assumptions also emerged in Bernard's advocacy of black rights at a volatile period of social upheaval in American history.

\section{Viola Bernard: medicine, McCarthyism and black rights}

Viola Bernard was the child of a German-Jewish couple Jacob Wertheim and his second wife, Emma Stern. Wertheim was the owner of the United Cigar Company and among the founders of the Federation of Jewish 
Philanthropies. His death in 1920 left his family in comfortable circumstances. ${ }^{3}$ Born in 1907 in New York City, Bernard undertook her undergraduate studies at Smith College, Barnard College, Johns Hopkins University and New York University. In 1936 she was one of only four women to receive her medical degree at Cornell University. Bernard completed her postgraduate work in psychoanalysis at the New York Psychoanalytic Society and Institute, from where she graduated in 1942. In 1945 she received her certification from the American Psychoanalytic Association. In the same year, she assisted Sandor Rado in establishing the Columbia University Center for Psychoanalytic Training and Research the first university-based training programme in the world.

Bernard's own case notes were less in the literary style of some analysts and more flavoured by her medical background. Case notes on black patients she may have analysed have yet to be located. Most of her cases were not written up for publication, but those accessible in her archived papers are illuminating for their discussion of sexuality: atypically for the time, she approached homosexuality neither as a pathology nor as a medical condition. When compared with European psychoanalysis, psychoanalysis in the USA was conspicuously medicalised as a profession. ${ }^{4}$ Despite this context for her practice, and although her training was firmly in medicine, Bernard did not always frame her examination of case histories in terms of medicalisation. ${ }^{5}$

A long-term social and political activist, during the $1930 \mathrm{~s}$, Bernard was a financial supporter of the People's Press, a trade unionist news service which was later attacked as a communist front organisation. She was active in civil liberties causes and during the 1950s was unofficially blacklisted as a person deemed unsuitable for US government employment. One of her key interests was the role that she believed psychiatry could play in empowering African-Americans. In the hostile ideological climate of the Cold War she encountered severe opposition to this idea, which propelled her into the political limelight.

In 1952 Bernard was at the pinnacle of her influence as a prominent New York psychiatrist, supporter of civil and liberal causes and a leading philanthropist. Also in 1952 she testified before the House Un-American Activities Committee (HUAC). Formed in 1938 to monitor German National Socialist activity, this committee of the US House of Representatives became best known for the interrogation of alleged communists. Promoted by Cold War warrior Joseph McCarthy, HUAC reached the peak of its influence during the 1940s and 1950s, when artists such as film directors and actors came under its scrutiny. Investigations resulted controversially in the blacklisting of the 'Hollywood Ten', driving those in the film industry underground, or forcing them to leave the USA altogether. ${ }^{6}$ Under J. Edgar Hoover as leader of the Federal Bureau of Investigation, psychoanalysts were subject to the closest scrutiny. Inevitably the focus fell on foreign-born analysts, but even those not foreign-born, like Bernard, did not escape surveillance. As Elizabeth Danto has argued, 
psychoanalysts often showed traits that were anathema to the "Americanism' of the day, namely a 'history of left-wing affiliations, an openness to sexuality, [they were] frequently atheists, and often Jewish'. Bernard displayed all of these traits, which collectively represented a catalogue of 'moral weakness'.

When asked about her affiliations, Bernard was direct and forthright in her testimony to HUAC. 'Politically', Bernard informed those judging her, 'I have always considered myself a liberal. I oppose totalitarianism of the left or right. I believe in the freedom and dignity of the individual and am convinced that these are best preserved and protected in a democratic society'. She believed her medical specialisations - in child welfare and mental health - to be a means of contributing to a 'better and healthier America'. Her exemplary record of public service, she argued, 'must prove that I am thoroughly loyal to my country and its institutions'. In this climate of surveillance and interrogation, Bernard's activity in a range of political causes was interpreted as mildly subversive at best and destructive at worst. Her testimony also coincided with the fervour and rapid rise of the civil rights movement, before it burst upon the political scene and developed into an unstoppable wave that engulfed American society. ${ }^{9}$

The recriminations that followed Bernard's testimony to HUAC were severe. Two years later, in 1954, Bernard was delisted as a consultant for the US Department of Health, Education and Welfare on the grounds of pro-communist activity. Such an attack upon a senior and influential member of the medical profession was unusual. It was based on Bernard's membership of several organisations: the American Committee for Protection of Foreign Born, and a number of other groups, including American Women for Peace, as well as her part ownership and financial support of a corporation that was community initiated and controlled - the People's Press. Bernard staunchly defended these connections as nothing more than loose affiliations, and asserted that her association with such initiatives did not reflect disloyalty. Bernard was also a member of the Physicians Forum Conference for Health Care Without Discrimination; she was a candidate for election to the board. The accusations of subversive activity become so pronounced that she resigned as a consultant to the US Public Health Service, and as a member of the Training Committee of the National Advisory Mental Health Council. The pressure became too much to bear:

there is no basis for questioning my loyalty to the US[.] I am submitting my resignation lest my continued association reflect adversely in the slightest degree on the National Mental Health Program. I value the importance of this Program so highly that I prefer resigning to the faintest risk of incurring even the most minimal handicap to this vital service for the mentally ill. ${ }^{10}$

Bernard believed that the "misuse of security measures' would increasingly exclude from service to the USA 'loyal and devoted professional 
individuals' who, in her view, had attempted to 'help solve social problems of vital importance to our democratic way of life'. ${ }^{11}$ Despite the manifest hostility towards her political standing, she remained steadfast in her determination to assist minority groups. This was especially apparent in her support for African-Americans in pursuit of careers in psychiatry. For example, in 1945 Bernard wrote to her colleague Dr Frederick Weil, thanking him for seeing twenty-year-old student Archie Parsons in order to administer a Rorschach test, the popular test used, especially in the post-war period, to observe personality and emotional states. This appointment was important to Bernard. Parsons was an AfricanAmerican student at the University of Michigan; he had sought advice from Bernard regarding the possibility of a career in psychiatry and she was keen to promote the option to him. In her letter to Weil, Bernard suggested that Weil charge his usual fee, but send the bill to her, which she paid from a fund used to support African-American students. The tests raised no concerns, and Bernard wrote to Parsons encouraging him to call on her if there was anything with which she could assist. ${ }^{12}$ Other African-Americans wrote to Bernard in deepest appreciation of her efforts to encourage them into psychiatry, even though they decided not to take that career path themselves. ${ }^{13}$ Bernard was a staunch supporter and provided strong letters of reference for African-American psychiatrists. The first African-American medical resident accepted into the Department of Psychiatry at Bellevue Hospital, Dr Charles Brown, received a glowing reference from Bernard. ${ }^{14}$

Yet, in the profession of psychiatry, the question of race was not unproblematic. Through the twentieth century, psychiatry had long been perceived as the enemy of minority groups. As such, in what ways did Bernard envisage that psychiatry would indeed provide a framework for liberation during the immediate post-war period? How did the Cold War thwart her progressive stance on the rights of African-Americans to enter into areas of medical practice such as psychiatry?

\section{'Mental hygiene' and minority groups}

In his comprehensive history of psychoanalysis in America, Nathan Hale has described 1945-65 as the period of the rapid rise of psychoanalytic psychiatry. In the American context, psychoanalysis - the practice based in Freudian principles and theories - emerged from the ashes and traumas of the First World War. The traditional methods of psychiatry, which involved an examination of mental disorders based on hereditary and neurological models, were increasingly challenged after the First World War by methods advocated by Freud and his followers. They favoured psychodynamic approaches that emphasised social and cultural factors. By the mid-twentieth century, psychoanalysis was becoming increasingly popular in America, and many psychiatrists with medical backgrounds 
began to train in this approach and to apply its methods. Bernard was one such medically trained psychiatrist who practised as a psychoanalyst. While psychiatry is medically based and psychoanalysis considers socio-cultural circumstances, both rely on individual case histories as a methodology and practice. ${ }^{15}$

Hale cites astonishing statistics concerning the importance of psychoanalysis after the Second World War. He notes that 78 per cent of those who took up psychiatry after graduating from the US army's neuropsychic training programme were psychoanalysed 'or planned to be psychoanalysed'. ${ }^{16}$ Private practice was on the increase. Hale estimates that, in 1947, more than half of all American psychiatrists were in private practice, or worked in outpatient clinics, a 20-30 per cent increase since 1940. By 1958, only 16 per cent of members of the American Psychiatric Association worked full-time in mental hospitals, reflecting a trend away from mental hospital services to those within a community setting. From 1948 to 1976, the numbers of qualified psychiatrists also increased, sixfold. This generation of younger psychiatrists emerged in the USA in the late 1950s, and dominated until the mid-1960s; each saw 'about seven patients a day for 45 or 50 minutes each, an average of three times a week for about 18 months'. ${ }^{17}$ Analysts from the preceding generation had prescribed drugs and shock treatments, and their treatments had differed. However, psychoanalysts held most of the teaching positions and dominated the psychiatric profession. Hale notes that the "new generation of analysts was a talented group, and by the 1960s they had assumed leadership of the American psychoanalytic movement and partially dominated American psychiatry'. ${ }^{18}$ Hale characterises the period between 1945 and 1965 as one of widespread popularity for psychoanalytic psychiatry in America. Psychoanalytic writings found expression in the popular arena through films, literature and magazines, and, over this period, ideas from Sigmund Freud found expression in a wide range of cultural forms. ${ }^{19}$

While acknowledging the shifting parameters of progressive psychiatry in post-war America, Hale's history does not, however, take into account the politics of race in psychoanalysis. A focus on race as a challenge to the discourse of psychiatry illuminates an unknown history that fundamentally reconceptualises our understanding of the importance of the civil rights movement for the development of modern psychiatry - and thus for the development of the psychiatric case study capable of acknowledging racial as well as sexual difference.

The issue of 'mental hygiene' had preoccupied black activist groups for decades. The year 1939 saw the formation of the Committee for the Development of Mental Hygiene Resources for Negroes in Raleigh, North Carolina. Rosa Kittrell initiated the movement. Kittrell was training to be a social worker when she experienced 'the onset of mental illness'. ${ }^{20}$ Through this experience she was moved to work for 'better psychiatric care for her people'. She wished to see created and to help create a 'hospital of high standards for the care of mentally ill Negro patients and 
for the training of professional workers in psychiatry and mental hygiene? Towards this end, she organised the White Plains Mental Hygiene Group, which eventually became the Committee for Mental Hygiene for Negroes. The aim was to establish several regional groups. By 1941, there were three in existence - in the cities of White Plains and New York, and in Alabama state. ${ }^{21}$ The Committee's constitution stipulated that its key purpose was to 'develop a movement to secure better Psychiatric and Mental Hygiene Recourses [sic] for Negroes ... [these] would appear to be best embodied in a Psychiatric Institute or Hospital incorporated in or attached to a Medical School'. ${ }^{22}$ The work of the Committee was regularly reported in the Journal of the National Medical Association. In 1943, when Bernard was part of the Harlem Clinic of the Board of Education Bureau of Child Guidance, the journal noted that she staunchly 'advocated the admission of Negro physicians to existing facilities in psychiatry. Dr Bernard pointed out that excellent training opportunities are open to Negroes in Social Work and Psychology but are very limited in psychiatry'. ${ }^{23}$

In Bernard's view, the crucial issue was provision of resources and opportunities for training more psychiatrists from within the AfricanAmerican community. Her campaign on this matter simultaneously addressed a wider issue that held importance for her: that of the therapeutic treatment of 'difference'. She considered it problematic that those identified with minority groups should be treated by those in majority groups. She asked how psychiatry handled the difference.

\footnotetext{
Inherent in psychiatric practice is an interpersonal relationship, charged with feeling. Inevitably inter-racial relationships are especially filled with emotion. The situation may become therapeutically impossible when patients of minority groups have emotional disturbances making them seek help, can only be treated by physicians of the majority group. The resultant tensions may well preclude the type of confidence in the doctor that is an essential part of good practice. This is not to say that Negro patients should necessarily go to Negro psychiatrists. There should, however, be available for all patients a varied range of therapists to meet different needs... To have only white psychiatrists available creates a wall at the outset. ${ }^{24}$
}

The benefit of such a varied range of therapists would also flow to the psychiatric community. Bernard observed that severe limitations and 'theoretical misconceptions' would follow if conclusions were "too often based on data from a middle-class white group, interpreted by investigators of the same social group. The psychiatric body of knowledge needs the contributions of colleagues who represent the whole community, including its Negro members'. ${ }^{25}$ Several clinics had opened in the Harlem area - the Harlem Hospital Clinic, the Northside Center for Child Development and the Bureau of Child Guidance - and 'all are struggling with overwhelming case loads', Bernard stated. Equally, she argued, leadership should come 'from the Negro community'. 
The barriers to leadership faced by African-Americans were deeply embedded within existing restrictions to education, since admission into medical colleges was strictly limited. Bernard believed that the twin evils of exclusion and segregation 'have placed a formidable barrier in the way of medical education for Negroes'; prejudice further barred the way to training in the specialties, including psychiatry. Nonetheless, she remained confident that social change could be ushered into the medical system. 'If upheaval is the forerunner of progress', she boldly proclaimed in 1948, "then we are on the threshold of major gains in the field of mental hygiene'. ${ }^{26}$

What was the upheaval Bernard had identified? The war years, she believed, had created a major shift 'on the whole question of psychiatry'. She argued that there had developed 'a widespread acceptance of the fact that psychiatric guidance is needed by millions of children and adults who are not actually or potentially insane'. Mental illness, she declared, had been recognised as an illness, not a scandal. Recent discoveries and developments in psychiatry had suggested progress in the field: drug therapy combined with psychotherapy; shock treatment; group therapy. These "advances have served to diminish greatly the sense of hopelessness which has long permeated the whole area of mental illness. An equally significant development has been the use of clinical teams of psychiatrists, psychologists and social workers'. ${ }^{27}$

A major deficiency that Bernard identified was in the area of training the 'Negro' psychiatrists, whom she considered vital to the assistance of black communities. The wider politics of race loomed large in her promotion of the training of such psychiatrists. The onus was on white, middle-class psychiatrists, who needed to move beyond their racialised conceptions and recognise the inner life of all, not just white, communities:

As psychiatrists in the United States in 1947, we need to understand intimately the inner mental life and meaning of behavior of the total population with its many social, economic and racial groups. Some of our theoretical misconceptions are doubtless traceable to the fact that conclusions are too often based on data from a middle-class white group, interpreted by investigators of the same social group. The psychiatric body of knowledge needs the contributions of colleagues who represent the whole community, including its Negro members. Many errors of theoretic concepts, based on incomplete sampling, could be corrected by teamwork between investigators of different ethnic and social deviation.

The 'Negro' needing psychiatric care could be accommodated only in state-run mental institutions - "private inter-racial sanatoria are practically non-existent' ${ }^{28}$ The few psychiatric facilities in the Harlem district, for instance, had employed very few specialists - "virtually the only private care the patient can seek is at the hands of a non-specialist'. Therefore, Bernard claimed, 'Negro' patients who could afford and would prefer to be treated in 'private inter-racial sanitoria' were nonetheless 
committed to state hospitals. The way to improve this situation would be to increase the number of 'Negro' psychiatrists and interracial services. Bernard believed that the solution to the overall problem largely depended upon the 'Negro' community taking some leadership itself. ${ }^{29}$ Towards this end, Bernard tackled the discrimination inherent in the medical schools and colleges. There were very few medical colleges who admitted 'Negro' students, and the few 'Negro' admissions to those institutions represented no more 'than a token'. The medical profession more generally had tried to draw attention to the plight of 'Negroes'; National Health Negro Week took place in 1944 to highlight the poor health of African-Americans. ${ }^{30}$

The psychoanalyst, too, Bernard believed, needed to take account of 'his own cultural position and social attitudes', conscious and unconscious, "with particular reference to prejudice'. This belief informed her larger platform of training analysts from a wider range of ethnic, religious and social backgrounds. For Bernard the need for sociologically inclusive training constituted a major issue, with notable implications for countertransference. She held that the "respective subcultural groups to which patient and analyst belong can be regarded as constituting a special dynamic factor of the analytic situation and as such can be provocative of countertransference? ${ }^{31}$

Bernard examined the different aspects of the patient-analyst dynamic, but the issue of prejudice was one in which she was most interested to explore the implications of the background of patient and analyst. "We know that the personal training provided the major safeguard against countertransference hazards, but often the unconscious foundations and psychodynamics of prejudice have not been worked with and worked through in the analyst's own analysis'. ${ }^{32}$ As such, Bernard believed the 'personal training' of psychoanalysts to be inadequate. If an analyst has insufficiently analysed 'his own unconscious material' pertaining

to his own group memberships and those of others, he and his patients may be insufficiently protected from the transference of a variety of positive and negative countertransference reactions stimulated by the ethnic, religious and racial elements that are present in the analytic situation, the patient's personality, and in the specific content of the patient's material. ${ }^{33}$

Bernard was acutely aware of the black-white divide informing these discussions. 'Although', she observed, the white analyst 'may be a member of a minority group, such as Jewish, he is also a member of the dominant white majority, vis-à-vis the Negro patient'. ${ }^{34}$ How is this often negotiated? It needs to be done carefully and delicately, but denial is the typical response. On the other hand, the analyst must avoid becoming caught up 'in exaggerating his response to the patient as a Negro rather than as an individual whose total being and specific life experience, including that of being colored, is the analyst's natural field of interest'. ${ }^{35}$ To Bernard, it appeared that, while some white analysts 'seem compelled to overemphasize the effects of being Negro on their patient's personality 
difficulties, others have an apparent need to deny and sidestep any such effects altogether' ${ }^{36}$ Either of these options seemed 'fallacious' to her, as they reflected 'a preconceived bias on the part of the analysts who should, instead, themselves be guided by what the material reveals' ${ }^{37}$

In Bernard's view, there was a real danger that a 'Negro' stereotype would emerge, "the psychoanalytic stereotype - whose frustrations will always come back to race'. While urging analysts to examine their own cultural experience, she did not wish to begin constructing the "white analyst' in a stereotyped manner. She argued strongly for closer 'cultural matching', because, according to her understanding, 'the negative emotional experience still overwhelmingly exceeds the positive experience between white and Negroes'. ${ }^{38}$ Bernard suggested that analysts recognise more and more "the need for informing themselves as fully as possible about social and cultural processes and patterning'. ${ }^{39}$ Ahead of her time, then, she saw an imperative to undertake transcultural analyses, "whereby the analyst's understanding of social and cultural meaning is extended and deepened'. ${ }^{40}$ Bernard advised analysts to scrutinise their 'motivations, attitudes and expectations' when embarking on psychoanalysing members of the African-American community. This was necessary at least until "prejudice and discrimination are significantly reduced in the general social setting' ${ }^{41}$

\section{Psychoanalytic ideas}

In advocating for analysts from a wide background to be admitted into training programmes, Bernard also argued for a more transcultural analysis to be incorporated into psychoanalytic discourse in America. In doing so she was giving voice to ideas that were widely in circulation; others had already discussed racial issues in terms of transference, countertransference and race. ${ }^{42}$ Indeed, during the $1950 \mathrm{~s}$ and $1960 \mathrm{~s}$, transference and countertransference in interracial analyses had become a major preoccupation among some analysts. In their discussion of this topic, published in 1968 in the Journal of the American Psychoanalytic Association, analysts Judith Schachter and Hugh Butts found it necessary to be cognisant of the 'current social revolution' and its impacts on the analytic relationship.

Many patients are involved in the interracial tensions which permeate our society. The major efforts being made to upset the structured patterns of discrimination are an important factor in the patient's awareness of choice and increase the possibilities of interracial analysis. We do not discuss, although we recognise, that on the conscious level, Negro-white relationships are directly related to the values, ethics, group norms, and sociopolitical philosophy of participants, and this fact plays a part in the material both patient and analyst choose to work with as well as in the nonverbal cues the patient receives. ${ }^{43}$ 
The authors drew the conclusion that, while racial differences between analyst and patient involve 'issues of unconscious meaning at various levels analogous to differences in sex between analyst and patient', only 'rarely do they create an either unanalysable barrier or a serious obstacle to treatment'. In their consideration of several cases, Schachter and Butts believed that while interracial analysis indicates "the difficulties to be anticipated", "these are apparently no greater than the obstacles encountered in analyses in which race is not an issue'. Such sentiments were not confined to professional exchanges between analysts, but influenced the wider population.

In the following decades Bernard's activism in support of permitting more 'Negroes' to enter medical school remained a key aspect of her personal and public discussions regarding the question of race and psychoanalysis. The year 1976 found her continuing her campaign. In correspondence with John Rhoads, then Professor of Psychiatry at Duke University, she revealed the way in which this issue had remained a preoccupation for her. 'The medical school has a reasonable proportion of blacks', observed Rhoads, 'but none seem to be interested in going into psychiatry. In fact, in the last several years, we recruited the only one who was interested. I'm not sure what the reason for this is, but it certainly is a matter of concern'. He also shared another concern with Bernard that of the "problem of middle-class therapists in dealing with patients from different cultural backgrounds'. ${ }^{44}$ Discussions on the same issue had been continuing in various medical journals. In 1970 Maynard Calnek published an article titled 'Racial Factors in the Countertransference: The Black Therapist and the Black Client' in the American Journal of Orthopsychiatry, arguing that the 'American racial situation' had created difficulties in 'working successfully with black clients'. He maintained that 'racial factors must be acknowledged and dealt with by the therapist', and that the black community and black therapist "should be the reference points for diagnosis and therapy with any black person' ${ }^{45}$

During the 1970 s race was hotly debated as a case study topical for the practice of psychiatry, and of more general, public importance. For example, in 1970 the Psychiatric Society of Westchester County's Committee on Social Issues presented a 'position paper' on 'white racism'. The Committee was chaired by Norbert Bromberg, who noted that the paper was not a 'scientific' paper, but was meant to

contribute to the public's understanding of those aspects of an issue in which the organization issuing the statement has some expertise. Unlike the scientific paper, it does not attempt to add to the scientific knowledge of the specialist, nor even to be an exhaustive and complete study of the subject, although such a study should be undertaken by the authors of the statement.

The organisation undertook to examine this subject because there were "psychological factors beyond those of other group prejudices that are important for psychiatrists and the public to understand'. ${ }^{46}$ 
This position paper is especially compelling, since, in directly linking racism with psychiatry, it offers a key context for understanding the milieu in which Bernard's activism took place, and within which psychiatry and psychoanalysis were endowed with a political purpose. The paper expounds how racism 'is rooted' in the 'conscious' and the 'unconscious', the authors believing it 'hardly possible for any white man in the United States to be completely free of at least unconscious racism, so pervasive is it in our culture'. From this prevalence it follows that, 'in times of stress, even the most liberal and enlightened may regress to racist stereotypes and preconceptions'. The psychological and psychiatric assessment was easily made. Racism was to be found in 'residuals of a very early phase of development in which images of others and self-images are regarded as "all good" or "all bad"".

[The] more completely this split persists, the less subject it is to rational modification. The blatant racist preserves an essentially 'all good' image of himself, which he protects from contamination by projecting the 'all bad' onto the black man. The Black, consequently, may be seen as indolent, suspicious, deceitful, violent, dirty, or salacious, i.e., possessing whatever traits the white man would find objectionable in himself.

Even when 'whites' have a 'better' conception of this characterisation, 'the Black's position in our society makes him an available object for the projection of unacceptable impulses and also for direct discharge of sadistic drives. Slavery, after all, was rationalized by the fiction that black people were subhuman'. ${ }^{47}$ On a clinical level, the authors observed that the 'degrading' conditions in which black people were living constituted 'a severe hazard to personality development': 'early and repeatedly the black child is made aware that black men live in a child-like, passive, feminine, and inferior position vis-à-vis white men'.

The response of the white man, too, is described as complex: 'racist cultural values offer ... infantile solutions to psychic conflicts over love and hate'. The expression of this is set forth as a "sense of entitlement, self-aggrandizement and denigration of others. The same is true of any Black extremist who develops his own racism. In the White racist, in place of identification with Blacks as fellow humans, there is sadism which reinforces infantile elements in his personality'. The report concluded that an "understanding of these irrational forces and factors in the psychological structure of racism is indispensible to its elimination'. ${ }^{48}$

The paper's proposed 'solutions' and actions for psychiatrists and psychologists are telling. They include distinctive recommendations for action by the Psychiatric Society of Westchester County. 'Most psychiatrists are of white middle-class background'; it was the responsibility of the individual to 'remove one's blind spots'. In clinical practice the psychiatrists' responsibilities included paying 'more attention ... to racist attitudes in the course of therapy with White patients'. Significantly, however, the paper stipulated that "psychiatrists should be in the forefront 
of those interpreting racism to the community' - by promoting leadership positions to members of all races, which would further cooperation between the races and help to combat racism as a cultural value. The critical assessment of some members of the profession in relation to racism remains striking. "Some psychiatrists view the black struggle with condescension and subtle defensiveness, eventually sacrificing human understanding to rhetoric which defends the status quo' ${ }^{49}$

Black activists themselves were not always convinced of the productive use of psychoanalysis or psychiatric case studies for the black population. Moreover, the question of whether 'a white psychiatrist can actually psychoanalyse a Negro under pressure of racial conflict' drew vitriolic and sharp responses from black activists, such as the outspoken and strident black journalist James Hicks. Hicks was a pioneering correspondent who edited the New York Amsterdam News from 1955 to 1966 and again from 1972 to 1977. During this time, the Amsterdam News became one of America's most widely circulated and most influential weekly newspapers on black rights. During the civil rights movement of the $1950 \mathrm{~s}$ and $1960 \mathrm{~s}$, Hicks reported the incidents of violence throughout the country for the Amsterdam News. ${ }^{50}$ On the issue of psychoanalysis he was especially vocal. He noted that a group of psychiatrists

say that it is almost impossible for a white psychiatrist to psychoanalyze a Negro who is under the pressure of racial conflict (and what Negro is not under pressure) because since the white psychiatrist represents the image of the cause of the Negro's conflict, by tradition and force of habit will not permit the white psychiatrists to really look into his inner mind and see the turmoil within. It goes without saying that if the white man can't find what's wrong with the Negro he can't offer him any cure. ${ }^{51}$

In the same article Hicks stated emphatically, 'I'd like to make it plain that I agree with [this] group of psychiatrists - I know that NO white man could ever psychoanalyze me because I couldn't bring myself to tell a white man ALL my innermost thoughts, even if he took me on a ride to Paradise on Cloud 17'. ${ }^{2}$ He persisted in this vein, arguing that 'if ALL Negroes would tell white people what they really think of them many white people would commit suicide'. Furthermore, 'since I'm not going to tell him what he wants to know when I'm not under pressure - I KNOW I'm not going to tell him all the things that are on my mind when I'm under pressure'. ${ }^{53}$

The New York City government announced in 1961 that it planned to spend $\$ 90,000$ "to pay a "psychiatric patrol" from the Jewish Board of Guardians to float around Harlem to "watch" or "study" juvenile delinquents with a view toward snatching them off the streets and forcing them on some white psychiatrist's couch' ${ }^{54}$ The proposal focused on gang leaders in Harlem. Even the idea that the Youth Board of the City of New York would commit to such an initiative was 'insulting'. Hicks expressed his outrage at this 'idiotic' suggestion: 
Good, bad or indifferent, the children of Harlem belong to the parents of Harlem, and these parents are not going to sit idly by and let a group of people from the Jewish Board of Guardians, the Polish Board of Guardians, the Chinese Board of Guardians or any other 'board of guardians' experiment without permission on the minds of their children as if they were white mice or guinea pigs.... For the benefit of these ill-informed social scientists downtown, we would inform them that Harlem is not yet a 'compound' or 'reservation' set aside for Negroes where white scholars may conduct scientific experiments on the minds of Negroes. And the people of Harlem will never allow this area to become such a reservation. ${ }^{55}$

Hicks declared: 'let[']s curb juvenile delinquency this summer. But first, let['] s curb the delinquent adults on our Your Board!"56 If the very concept of a 'study' of black children by white experts disgusted Hicks, he found especially affronting any efforts to study them psychoanalytically. To Hicks, these efforts resonated with earlier 'scientific' experimentation by whites, when blacks were treated like 'guinea pigs'. Hicks was adamant that the political agenda intrinsic to studies of blacks by whites - whatever form the studies took - was highly offensive.

\section{Bernard and the role of psychology in challenging racial segregation}

Bernard assisted those working for racial equality beyond the medical sphere. In August 1959, prominent left-wing activist and rights agitator Carl Braden was charged with contempt of Congress and sentenced to a year's imprisonment 'for refusing to answer certain questions of him by a subcommittee of the House Un-American Committee in Atlanta Ga., in July, 1958. He challenged the committee's right to ask the questions.' Bernard paid his bail of $\$ 1,000$. As a celebrated activist for racial equality, Braden was the target of attacks by white supremacists and was barred from employment in Kentucky. He worked for the Southern Conference Educational Fund (SCEF) and developed its civil rights cause through the Southern Patriot, the organisation's monthly newspaper. ${ }^{57}$

Bernard took an exceptionally active role on the issue of segregation. In 1952 she was a signatory to a submission to the US Supreme Court that outlined the effects of the segregation of racial and ethnic groups. ${ }^{58}$ The Southern Patriot discussed this issue at length in 1956, and particularly the psychiatric benefits of integration. Pro-segregationists were claiming that 'mixing children in public schools would have harmful emotional effect on both races'. ${ }^{59}$ A survey conducted by the New Orleans Medical Association and the Medical Advisory Committee of the SCEF asked the following question: 'From a professional point of view, how would you characterize the psychiatric effect of racially integrated schools on white and Negro children?' The results revealed a greater openness to desegregation than might have been expected. Eighteen doctors thought that 'integration 
would either be beneficial or would have little effect'; eleven 'declared it beneficial'; of the seven anticipating it to have little effect, three qualified their answers with 'in the long run'. Four 'considered there were harmful possibilities in the ending of segregation'. Two "thought both races would suffer; one believed that whites would be harmed while Negroes would benefit' ${ }^{60}$

Bernard's view on this question was clear. The notion of desegregation was not perfect, but it was the better option and any difficulties that might arise from it could be treated.

With desegregation some Negro children will probably feel discrimination in more personally-directed and immediately painful forums than in their all-Negro schools. But at least this form of trauma is more accessible therapeutically than the chronic indirect hurt to personality of legally sanctioned exclusion and restriction. ${ }^{61}$

Of the two conditions, then, desegregation was the lesser of evils.

As the choice of the lesser evil it seems preferable, from the mental-health standpoint, for some Negro children to suffer the transitional and current psychological hardships of desegregation which are relatively more recognisable and correctable, than to experience the more insidious and less treatable life-long psychic damage from segregation. ${ }^{62}$

Other psychiatrists agreed. One 'young, Louisiana-born doctor' commented in the following way on segregation in schools:

There can be little question of the detrimental effect on the psychic development of any discriminated-against group, by a system which teaches them that they are inferior, but which requires them to compete for the necessities and niceties of life on an equal economic level. The results, in decreased contentment, undeveloped potential, and the fostering of resentments and hostility likely to be acted out against the frustrating community, should be obvious. ${ }^{63}$

Ideas about the impact of racial and ethnic integration on the white population were the source of some contention. It was a 'complex subject', noted the same young doctor, 'but since there are no demonstrable biological differences between races on any significant level, there can be no advantage for a group to grow up with the belief, totally false, that they are significantly better, and thus entitled to greater privilege and more of the world's goods. This does not produce mature people' ${ }^{64}$ Another medical doctor commented on the 'emotional transition' that segregation would entail:

Initially there is likely to be some reserve and suspiciousness on the part of both races. Especially in the upper grades the children will at first try to remain separate and associate only with their own color. Some, inflamed by their elders, may become involved in fighting. 
It was predicted that, over time, however, children would cease to see only colour differences and would gradually

come to accept the individuals of the other race according to each one's worth as a student and a human being. The ultimate effect will be a lessening of irrational prejudice generally.... The Negro children will live with less fear, envy and suppressed hostility towards whites. In turn the white children will have less irrational fear of Negroes and less guilt feelings towards them. ${ }^{65}$

Others believed in the necessity of a gradual adaptation to desegregation. 'I favor a gradual integration beginning first with kindergarten and in 13 years integration will be complete. A sudden, cataclysmic change can only lead to disaster!' Dr Martial Boudreaux wrote with a strident voice:

The fears that any mixture of the races will lead to increases of disease, significant lowering of intelligence, or psychiatric difficulties in either race, to my view are unfounded.... These methods of rationalization are common in history. They, in one form or another, have been used to give a pseudo-logical or scientific front for action that has motivations other than the stated ones. Hitler used them effectively in Germany, except the prejudice was primarily against the Jew rather than the American Negro. Perhaps it is forgotten that one of the reasons we fought so hard in World War II was to assert that racial intolerances were not compatible with freedom and democracy. ${ }^{66}$

The matter of public health in general was much debated in the Southern Patriot. One paediatrician in the 'integrated city' of St Louis commented:

child health, particularly in the South, where so much domestic work is done by Negroes, cannot be segregated.... With regard to school contacts, whether with teachers or pupils, if the school hygiene program of observation and examination of children is well and conscientiously conducted ... integration should have no appreciable effect upon the children's health. So far, it certainly has not. ${ }^{67}$

Alfred Yankauer, another medical doctor, dismissed segregationists because their views were not 'based upon logic and therefore not answerable by logic. In fact, there are harmful effects of inferior housing, dense populations and inadequate facilities' ${ }^{68}$

Bernard was perhaps most directly involved in the cause of public health and its relation to segregation through her support of the court cases litigated by the National Association for the Advancement of Colored People (NAACP) and its Legal and Educational Fund against state laws 'which required segregated schools [and] violated the equal protection clause of the Fourteenth Amendment of the United States Constitution' The NAACP has a long history in the civil rights movement. Founded in 1909, its guiding principle was to fight for equal citizenship rights for 
African-Americans. When the Association was formed, open violation of civil rights and lynching of blacks continued, despite the Thirteenth, Fourteenth and Fifteenth Amendments to the US Constitution which had been adopted between 1865 and 1870, and which explicitly enshrined equal political rights for all, as well as the illegality of denying the right to vote on the grounds of 'race, color, or previous condition of servitude'. ${ }^{69}$

The NAACP fought for full desegregation. Since the late 1940s, psychologist Kenneth Clark had been collecting material on the damage that segregation caused to children. Clark's work was not confined to schools. He and his researchers had been charting the effects of segregation in housing, employment and health, and on the learning capacities of white and 'Negro' children. With this research in hand, the NAACP took the next step in its campaign against segregation. ${ }^{70}$ At a meeting in 1950 , all members of the NAACP, including its branch and state conferences, decided to tackle the question of educational segregation in a bold move; the psychical and psychological harm of segregation was immediate and devastating in its impact on 'Negro' children, and action needed to be swift and direct. ${ }^{71}$ As part of this strategy, Robert L. Carter, a lawyer in the NAACP, decided to draw on the wider expertise and knowledge of a range of specialists, including psychiatrists, psychologists and social scientists such as sociologists and anthropologists, to produce material explaining the detrimental impact of segregation on 'Negro' children. ${ }^{72}$ Bernard was one such specialist who became involved in the enterprise of writing up and publicising the relevant studies.

In a landmark decision of May 1954, Brown v. Board of Education, the US Supreme Court found segregation in schools to be unconstitutional. Bernard assisted with the preparation of this case, especially in terms of the medical and psychological impact of desegregation. In developing material for the court case, Carter, the Assistant Counsel, wrote to Bernard in October 1952, to express appreciation of her efforts. Carter was fulsome in his praise of the work she had done and the material she had provided:

It is difficult to express in words our gratitude and elation for your support and generous cooperation. Certainly, we realize that if we succeed in destroying the legal foundation upon which segregation is based in these or in subsequent cases, most of the credit must go, not to us lawyers, but to those social scientists who have made it possible to demonstrate the injurious and hurtful consequences of segregation as a pattern of American life. ${ }^{73}$

In June 1954, shortly after the historic ruling in Brown v. Board of Education, Carter wrote to Bernard in ecstasy over their success. In a moving letter he again expressed his thanks for her assistance:

You are undoubtedly as overjoyed as we with the May 17th decisions of the United States Supreme Court in the school segregation cases. It now 
seems certain that the basic objectives of the NAACP's legal program elimination of legally enforced segregation and discrimination in all aspects of American life - will be realized much sooner than any of us had dared hope. While the staff here feels justly proud in being on the winning side of such a great issue, all of us realize that we did not and could not have done this job alone. ${ }^{74}$

In the context of this victory, Carter wrote in powerful terms of Bernard's indispensable role:

You were one of those who greatly aided in the successful preparation, development and presentation of the theory which won the vote for the Court. I wish to express to you on behalf ... [of] our entire staff, our deep and sincere appreciation for the part you played in what may well be one of the greatest victories for democracy in our generation. ${ }^{75}$

The NAACP looked to the future for further support from Bernard:

Much remains to be done. Having contributed so much, we feel confident that we can include you among those to whom we can turn for help in the planning and implementation of a sound program designed to give effect to the May 17th ruling at the community level and in extending that ruling to other areas. While the task ahead is formidable indeed, all of us, I believe, feel we can now approach that difficult job with high optimistic hope. ${ }^{76}$

Bernard's involvement in the pursuit of desegregation in schools across the USA continued. In July 1954, a conference of social scientists for the legal division of the NAACP convened to consider several issues associated with segregation. Discussion focused on the key question of the pace of desegregation: there were forms of 'gradual' transition and there were forms of 'immediate' desegregation. Central to these considerations were the "doubts and anxieties concerning the readiness, the procedure by which and the rate at which the general public can accept changes in race relations.... It is assumed that the period of preparation and education will reduce resistance or opposition to desegregation or other changes in racial practices'. ${ }^{77}$ The pace of change was a major concern for Bernard, and she stressed the importance of highlighting the shift in public opinion on this issue. She wrote to Clark,

Doesn't the evidence show in employment, housing, and military desegregation, that reform for integration grew out of changed and growing public feeling for integration sufficient to create the necessary pressure for the reform - and that then the legally enforced and sanctioned policy of desegregation induced the necessary social behavior. ${ }^{78}$

Shifts had already taken place in public opinion, "as evidenced by the steps towards - the fact of - the reactions to - the Supreme Court Decision'. According to Bernard, the best move forward was to ensure that the legal sanctions had been implemented. 'The unequivocal decree of the court, 
and the setting up thereby [sic] of the strongest legal sanctions and enforcement would offer the best means of creating the further attitudinal climate for smooth and effective implementation'. ${ }^{79}$

The September 1952 submission to the US Supreme Court titled 'The Effects of Segregation and Consequences of Desegregation: A Social Science Statement' articulated the psychological thinking of progressives of the time, like Bernard. The concept of the 'inferiority complex' was central to a discussion of self-worth and conflict. One finding stated:

as minority group children learn the inferiority status to which they are assigned - as they observe the fact that they are almost always segregated and kept apart from others who are treated with more respect by the society as a whole - they often react with feelings of inferiority and a sense of personal humiliation. Many of them become confused about their own personal worth. ${ }^{80}$

Indeed, personal dignity, self-respect and conflict were themes that emerged from the statement to the Supreme Court:

On the one hand, like all other human beings they require a sense of personal dignity; on the other hand, almost nowhere in the larger society do they find their own dignity as human beings respected by others. Under these conditions, the minority group child is thrown into a conflict with regard to his feelings about himself and his group. He wonders whether his group and he himself are worthy of no more respect than they receive. This conflict and confusion leads to self-hatred and rejection of his own group. ${ }^{81}$

To consider why segregation produces this impact, it was necessary to bring to bear on the issue insights from psychological and sociological knowledge. Such insights included 'the role of various environmental influences in producing feelings of inferiority, confusions in personal roles, various types of basic personality structures and the various forms of personal and social disorganization'. The emphasis here was on 'feelings of inferiority and doubts about personal worth', which involved an awareness of 'social status difference'. Enforced segregation produced flow-on effects, such as defeatism and a low level of aspiration among children in segregated schools. Moreover, minority group children displayed a hypersensitivity and anxiety about their relations with the larger society. ${ }^{82}$ Segregation had the potential to be detrimental to all children, although for children in the majority group, the effects were comparatively obscure. These children learn 'the prejudices of society' and are taught 'to gain personal status in an unrealistic and non-adaptive way'. The culture then condones 'hostility and aggression against whole groups of people' believed to be weaker than the majority group. ${ }^{83}$ Those subject to segregation often 'develop patterns of guilt feelings, rationalizations and other mechanisms which they must use in an attempt to protect themselves from recognizing the essential injustice of their unrealistic fears and hatreds of minority groups' ${ }^{84}$ 
The problem of violence was mentioned as a significant source of ongoing concern. The submission document included the observation that studies of "urban riots ... found that race riots occurred in segregated neighborhoods', while there was 'no violence in sections of the city where the two races lived, worked and attended school together'. ${ }^{85}$ An important message of the argument set forth in the Social Science Statement related to intelligence, and the supposed inferior intelligence of minority groups. It declared that 'fears based on the assumption of innate racial differences in intelligence are not well founded'. ${ }^{86}$ Submitted in September 1952 as the appendix to the appellant's brief in Brown $v$. Board of Education, the Statement was published eight months later in the Minnesota Law Review; it was at the forefront of promoting civil rights, by drawing on studies undertaken within the discipline of psychology. Bernard's role in generating the expert submission was central, and she provided much insight and energy to this enterprise.

The wave of resistance to the Supreme Court decision of May 1954 was immediate and sustained. Bernard's consideration of public opinion was germane. As white resistance heightened, the court ruling and the NAACP's belief in judicial rulings were to be severely challenged. For instance, the activities of the NAACP were effectively barred inside the boundaries of the State of Alabama, limiting its operations. ${ }^{87}$ The campaign for desegregation continued during the 1950s. In 1955, NAACP members Rosa Parks and Edgar ('E. D.') Nixon helped to spearhead the bus boycott in Alabama's capital city of Montgomery. The protest aimed to end racial segregation on the city's public transportation system. ${ }^{88}$ Eventually, the tactics of 'nonviolent mass protest, targeted litigation, and deft political lobbying had helped shatter the southern caste system. The Civil Rights Act of 1964 and the Voting Rights Act of 1965 dismantled the legal framework for segregation' ${ }^{89}$

Related to the issue of racial segregation was that of child delinquency. Bernard worked closely with the public school system to attempt to address this. In 1959, the Department of Public Welfare made publicly available statistics and information about the increasing rise of delinquency among poor children and white and 'non-white' children. ${ }^{90}$

\section{The Jewish community}

Viola Bernard's interests in cultural change and psychiatry extended to other kinds of advocacy, such as writing and speaking out against anti-Semitism. In 1945, Max Horkheimer from the American Jewish Committee had written to Bernard when the committee was searching for expertise on 'the nature and extent of anti-Semitism, particularly as it relates to psycho-dynamic motivations'. Horkheimer went on to note that they "should like ... to discuss this project with a group of leaders in the field and for that purpose are calling an initial meeting. ${ }^{91}$ 
The Jewish community's concern to understand support for German National Socialism continued into the 1960s, and the American Jewish Committee sought Bernard's advice, also assisting her with research into young people and their series of 'Swastika daubings'. ${ }^{92}$ The Committee's support for such research was not due to 'morbid curiosity', but to a wish for a fuller understanding of psychological and psychiatric issues behind such behaviours. Aggressive, public displays of anti-Semitic behaviour became an ongoing cause of concern across the USA. In 1960, Bernard was involved in discussions about increasing anti-Semitism and the links between these and 'crazes and fads of less destructive nature'. ${ }^{93}$ Her public comments drew the supportive attention of other doctors, such as Anthony Votos, who wrote to her: 'I couldn't help but write after reading your comments in today's Times. There is much more destructive hatred in today's anti-Semitic outbursts than even seemingly astute clinicians are willing to admit'. ${ }^{94}$

Of additional interest to Bernard was the question of Jewish identity, and several organisations and institutions sought her view on ways in which Jewish identity and the self might be addressed psychoanalytically. She conferred with her colleagues. In correspondence about the nature of anti-Semitism, others contacted Bernard regarding their psychoanalytic patients. In 1946, Bluma Swerdloff from the Department of Scientific Research contacted Bernard, raising questions about cultural shifts within Jewish families, and the impact of such shifts on family functioning. In relation to one particular patient of Bernard's, several questions were asked about responses to cultural change:

We learned in the background history that there were a number of inter-marriages in the maternal family. We were wondering what the mother's attitude was to her sister who married a non-Jew. There seemed to be much feeling about the brother who married a Gentile girl but little was said about the sister. ${ }^{95}$

The patient's attitude to 'Jewishness' became central to the discussion:

Did the parent have any reactions to the dependence of his parents on their relatives? We are interested in this because we feel that it might throw further light as to the parents' own attitude towards their Jewishness. It was our feeling, for instance, that the mother's ambivalent attitude to her own Jewishness is a reflection of her ambivalence to her mother. We are also concerned as to how the mother's attitude to Jewishness and her father's reflect themselves in the patient's attitude towards being a Jew. The fact of being Jewish seems to have different meaning for the father and the mother. The father seems to have a more ethical approach and the mother seems to accept some of the ritual without ideological understanding. ${ }^{96}$

Circumcision also becomes the focus of discussion, Bernard's correspondent noting that the patient's 'feeling about his own penis seems 
significant. Did he make any comments about circumcision? How does this patient compare how own penis $[$ sic $]$ with that of others, for example, his cousin Robert's?"97

In dedicating her activism to black and also Jewish causes, Bernard was part of an activist movement with a long-standing history in America. ${ }^{98}$ Her empathy for historically marginalised groups emerged from her own commitment to justice and equality - causes that she believed were vital for psychoanalysts to pursue. An examination of Bernard's efforts, both within and beyond the disciplinary sphere of psychiatry, to develop case materials in support of minority groups, especially in relation to the African-American community, is illuminating. Bernard's key contribution lies in her efforts to use the case study in psychiatry to explore issues of race in ways which she perceived were empowering to those from the African-American community. Furthermore, as a professional case writer, Bernard aimed to create a space for African-American psychiatrists themselves to become case writers, in ways which addressed issues of power, civil rights and self-determination at a time when these questions were at the forefront of American society.

This chapter also points to ways in which case studies can be overtly political - in terms of theorisation, at a professional level, and also with regard to wider movements for change in the broader society. It suggests, too, the difficulties of developing case narratives capable of convincing the public at large during particular historic moments, and within highly charged political environments. The $1940 \mathrm{~s}$ and $1950 \mathrm{~s}$ were characterised by rigid racial segregation and denial of human rights for America's black community. The immediate post-war period saw the dramatic rise of the civil rights movement. These issues and concerns placed Bernard at the progressive end of the racial politics of the day; none was a theoretical abstraction for Bernard. She was a key activist in establishing organisations and lobby groups for African-American rights, and in doing so provided expert knowledge to those agitating for reform.

Bernard's role as a medical expert in the campaign to end racial segregation in schools resonates strongly with Erich Wulffen's influence as a legal expert in the first decades of the twentieth century. As with Wulffen's career in the law, Bernard's career highlights the rise of the 'expert' in medicine. Although separated by time and place, the influence exerted by Wulffen and by Bernard was considerable, due in good part to recognition of their expertise; both shaped and were shaped by the political and legal culture of their respective eras. The case-based common law (or case law) of the USA enabled Bernard to change US regulations to the benefit of her cause, since by definition in a common law system a single case ruling has binding powers. In Wilhelmine and Weimar Germany, 
Wulffen experienced frustrations occasioned by the fact that German civil law responded extremely slowly to change. Yet the comparatively lesser importance of legal cases in his context also enabled him to reinvent the case study genre more radically, and target a range of readerships for promoting his ideas. Such differences point to two themes of the present volume: the historical contingency of all case study modalities, and hence ways in which they illuminate cultural and political developments of the day.

\section{Notes}

1 The use of the term 'Negro' in the present chapter reflects usage characteristic of the time and place under discussion.

2 See Joy Damousi, "Viola Bernard and the Analysis of "Alice Conrad": A Case Study in the History of Intimacy', Journal of the History of Sexuality, 22:3 (2013), pp. 474-500; Joy Damousi, 'Sexuality and the Public Case Study in the United States, 1940-1965', in Joy Damousi, Birgit Lang and Katie Sutton (eds), Case Studies and the Dissemination of Knowledge (New York: Routledge, 2015), pp. 133-51.

3 A. C. Long Health Sciences Library, Columbia University, New York City, Archives and Special Collections (hereafter CU), Viola Wertheim Bernard Papers, 1918-2000, 'Historical/Biographical Note', given at http://library-archives.cumc. columbia.edu/finding-aid/viola-wertheim-bernard-papers-1918-2000, accessed 29 June 2015.

4. Nathan G. Hale, The Rise and Crisis of Psychoanalysis in the United States: Freud and the Americans 1917-1985 (New York: Oxford University Press, 1995), pp. 3-9.

5 Damousi, "Viola Bernard and the Analysis of "Alice Conrad", p. 481.

6 John Joseph Gladchuk, Hollywood and Anticommunism: HUAC and the Evolution of the Red Menace, 1935-1950 (New York: Routledge, 2006).

7 Elizabeth Ann Danto, "Have you no Shame" - American Redbaiting of Europe's Psychoanalysis', in Joy Damousi and Mariano Ben Plotkin (eds), Psychoanalysis and Politics: Histories of Psychoanalysis under Conditions of Restricted Political Freedom (New York: Oxford University Press, 2012), pp. 213-32, p. 222. For Bernard's examination of sexuality, see Damousi, 'Viola Bernard and the Analysis of "Alice Conrad".

8 CU, Viola Wertheim Bernard Papers, 1918-2000, Box 311, Folder 3, 'Answers to Interrogatories'.

9 Robert Cook, Sweet Land of Liberty? The African-American Struggle for Civil Rights in the Twentieth Century (London: Longman, 1998), p. 112.

10 CU, Viola Wertheim Bernard Papers, 1918-2000, Box 311, Folder 2, Viola Bernard to Dr R. H. Felix, June 1954.

11 CU, Viola Wertheim Bernard Papers, 1918-2000, Box 311, Folder 2, Viola Bernard to Dr R. H. Felix, June 1954.

12 CU, Viola Wertheim Bernard Papers, 1918-2000, Box 341, Folder 9, Viola W. Bernard to Frederick S. Weil, 23 October 1945; Box 341, Folder 9, Viola Bernard to Archie Parsons, 4 December 1945.

13 CU, Viola Wertheim Bernard Papers, 1918-2000, Box 341, Folder 9, Garnet T. Ice to Viola Bernard, 12 April 1946; 15 February 1947.

14 CU, Viola Wertheim Bernard Papers, 1918-2000, Box 341, Folder 9, Viola Bernard to Dr B. E. Boothe, 4 June 1947.

15 Hale, The Rise and Crisis of Psychoanalysis, p. 246. 
16 Hale, The Rise and Crisis of Psychoanalysis, p. 246.

17 Hale, The Rise and Crisis of Psychoanalysis, p. 247.

18 Hale, The Rise and Crisis of Psychoanalysis, p. 247.

19 Hale, The Rise and Crisis of Psychoanalysis, pp. 276-99.

20 CU, Viola Wertheim Bernard Papers, 1918-2000, Box 338, Folder 4.2, Records Documenting 'A Committee for Mental Hygiene for Negroes'.

21 CU, Viola Wertheim Bernard Papers, 1918-2000, Box 338, Folder 4.2, Records Documenting 'A Committee for Mental Hygiene for Negroes'.

22 CU, Viola Wertheim Bernard Papers, 1918-2000, Box 338, Folder 4.1, 'The Committee for the Development of Mental Hygiene Resources for Negroes: Constitution and By-Laws'.

23 Journal of the National Medical Association, 35:4 (July 1943), p. 146.

24 CU, Viola Wertheim Bernard Papers, 1918-2000, Box 384, Folder 11, Viola Bernard, 'Mental Hygiene and the Negro Community', unpublished article, 1948, pp. 1-7, p. 5 .

25 Bernard, 'Mental Hygiene and the Negro Community', unpublished article, 1948, p. 5

26 Bernard, 'Mental Hygiene and the Negro Community', unpublished article, 1948, p. 7.

27 Bernard, 'Mental Hygiene and the Negro Community', unpublished article, 1948, p. 1.

28 Bernard, 'Mental Hygiene and the Negro Community', unpublished article, 1948, p. 5.

29 Bernard, 'Mental Hygiene and the Negro Community', unpublished article, 1948, p. 6.

30 Documented in the Journal of the National Medical Association, 36:4 (1944), p. 118; also 36:6 (1944), p. 202.

31 Journal of the National Medical Association, 36:4 (1944), p. 118; also 36:6 (1944), p. 202.

32 Viola Bernard, 'Psychoanalysis and Members of Minority Groups', Journal of the American Psychoanalytic Association, 1:2 (1953), pp. 255-68, p. 258.

33 Bernard, 'Psychoanalysis and Members of Minority Groups', p. 259.

34 Bernard, 'Psychoanalysis and Members of Minority Groups', p. 259.

35 Bernard, 'Psychoanalysis and Members of Minority Groups', p. 261.

36 Bernard, 'Psychoanalysis and Members of Minority Groups', p. 262.

37 Bernard, 'Psychoanalysis and Members of Minority Groups', p. 262.

38 Bernard, 'Psychoanalysis and Members of Minority Groups', p. 265.

39 Bernard, 'Psychoanalysis and Members of Minority Groups', p. 266.

40 Bernard, 'Psychoanalysis and Members of Minority Groups', p. 266.

41 Bernard, 'Psychoanalysis and Members of Minority Groups', p. 263.

42 Judith S. Schachter and Hugh F. Butts, 'Transference and Countertransference in Interracial Analyses', Journal of the American Psychoanalytic Association, 16:4 (1968), pp. 792-808.

43 Schachter and Butts, 'Transference and Countertransference in Interracial Analyses', pp. 792-3.

44 CU, Viola Wertheim Bernard Papers, 1918-2000, Box 335, Folder 2.1, John M. Rhoads to Viola Bernard, 27 May 1976.

45 Maynard Calnek, 'Racial Factors in the Countertransference: The Black Therapist and the Black Client', American Journal of Orthopsychiatry, 40:1 (1970), pp. $39-46$, p. 45.

46 CU, Viola Wertheim Bernard Papers, 1918-2000, Box 340, Folder 4.5, Norbert Bromberg to Alexander Carlen, 23 July 1970.

47 'Report of Ad Hoc Committee on Social Issues. Position Paper: White Racism', Presented by the Psychiatric Society of Westchester County's Committee on Social Issues, 1970, p. 1, sourced at CU, Viola Wertheim Bernard Papers, 
1918-2000, Box 340, Folder 4.5. Note that all relevant quotations herein reproduce the inconsistent capitalisation found in this source.

48 'Report of Ad Hoc Committee on Social Issues: Position Paper: White Racism', p. 1.

49 'Report of Ad Hoc Committee on Social Issues: Position Paper: White Racism', p. 1.

50 Wolfgang Saxon, 'James Hicks, 70, Journalist, Ex-Amsterdam News Editor' (Obituary), New York Times, 22 January 1986, www.nytimes.com/1986/01/22/ obituaries/james-hicks-70-journalist-ex-amsterdam-news-editor.html, accessed 4 May 2015.

51 James L. Hicks, 'Tired Guinea Pigs', New York Amsterdam News, 20 May 1961, n.p., news clipping sourced at CU, Viola Wertheim Bernard Papers, 1918-2000, Box 341, Folder 13.2.

52 Hicks, 'Tired Guinea Pigs'.

53 Hicks, 'Tired Guinea Pigs'.

54 Hicks, 'Tired Guinea Pigs'.

55 James L. Hicks, 'Who's Delinquent?', New York Amsterdam News, 20 May 1961, n.p., news clipping sourced at CU, Viola Wertheim Bernard Papers, 1918-2000, Box 342, Folder 1.2.

56 Hicks, 'Who's Delinquent?'

57 CU, Viola Wertheim Bernard Papers, 1918-2000, Box 338, Folder 10.2, 'News from Southern Conference Educational Fund'; Box 338, Folder 10.1, Jim Dombrowski, Executive Director, Southern Conference Educational Fund, to Dr Bernard, 5 February 1959; Box 338, Folder 10.5, Records Documenting Carl Braden v. US (1961); Box 338, Folder 10.1, Pittsburgh Courier and New York Courier, 22 April 1961, news clippings.

58 CU, Viola Wertheim Bernard Papers, 1918-2000, Box 343, Folder 3.13, 'The Effects of Segregation and the Consequences of Desegregation: A Social Science Statement', Supreme Court of the United States, 1952.

59 Southern Patriot, 14:5 (1956), p. 1.

60 Southern Patriot, 14:5 (1956), p. 1.

61 Southern Patriot, 14:5 (1956), p. 1.

62 Southern Patriot, 14:5 (1956), p. 1.

63 Southern Patriot, 14:5 (1956), p. 1.

64 Southern Patriot, 14:5 (1956), p. 1.

65 Southern Patriot, 14:5 (1956), p. 1.

66 Southern Patriot, 14:5 (1956), p. 1.

67 Alfred Yankauer, Southern Patriot, 14:5 (1956), p. 4.

68 Yankauer, Southern Patriot (1956), p. 4.

69 Adam Fairclough, 'Foreword', in Kevern Verney and Lee Sartain (eds), Long Is the Way and Hard: One Hundred Years of the National Association for the Advancement of Colored People (NAACP) (Fayetteville: University of Arkansas Press, 2009), p. vii.

70 Gilbert Jonas, Freedom's Sword: The NAACP and the Struggle Against Racism in America, 1909-1969 (New York: Routledge, 2005), pp. 55-6.

71 Jonas, Freedom's Sword, p. 58.

72 Jonas, Freedom's Sword, p. 58.

73 CU, Viola Wertheim Bernard Papers, 1918-2000, Box 343, Folder 3.1, Robert L. Carter to Viola Bernard, 6 October 1952.

74 CU, Viola Wertheim Bernard Papers, 1918-2000, Box 342, Folder 3.1, Robert L. Carter to Viola Bernard, 23 June 1954.

75 CU, Viola Wertheim Bernard Papers, 1918-2000, Box 342, Folder 3.1, Robert L. Carter to Viola Bernard, 23 June 1954.

76 CU, Viola Wertheim Bernard Papers, 1918-2000, Box 342, Folder 3.1, Robert L. Carter to Viola Bernard, 23 June 1954. 
77 CU, Viola Wertheim Bernard Papers, 1918-2000, Box 343, Folder 3.12, 'Summary and Integration of Discussion and Conclusions of the 23 July 1954 Conference of Social Scientists'.

78 CU, Viola Wertheim Bernard Papers, 1918-2000, Box 343, Folder 3.5, Viola Bernard to Ken (Kenneth Clark), 14 August 1954.

79 CU, Viola Wertheim Bernard Papers, 1918-2000, box 343, folder 3.5, Viola Bernard to Ken (Kenneth Clark), 14 August 1954.

80 Kenneth B. Clark, Isidor Chein and Stuart W. Cook, 'The Effects of Segregation and the Consequences of Desegregation: A Social Science Statement', Brief Filed with the US Supreme Court on 22 September 1952, p. 4, sourced at CU, Viola Wertheim Bernard Papers, 1918-2000, Box 343, Folder 3.13. The brief appeared under the same title in the Minnesota Law Review, 37 (May 1953), pp. 427-38.

81 Clark, Chein and Cook, 'The Effects of Segregation and the Consequences of Desegregation', p. 4.

82 Clark, Chein and Cook, 'The Effects of Segregation and the Consequences of Desegregation', p. 9.

83 Clark, Chein and Cook, 'The Effects of Segregation and the Consequences of Desegregation', p. 6.

84 Clark, Chein and Cook, 'The Effects of Segregation and the Consequences of Desegregation', p. 6.

85 Clark, Chein and Cook, 'The Effects of Segregation and the Consequences of Desegregation', p. 15.

86 Clark, Chein and Cook, 'The Effects of Segregation and the Consequences of Desegregation', p. 12.

87 Yvonne Ryan, 'Leading from the Back: Roy Wilkins's Leadership of the NAACP', in Verney and Sartain (eds), Long Is the Way and Hard, pp. 43-58, p. 47.

88 For a detailed examination of the Montgomery bus boycott, see Taylor Branch, Parting the Waters: America in the King Years, 1954-63 (New York: Simon \& Schuster, 1988), pp. 143-205.

89 Simon Hall, 'The NAACP and the Challenges of 1960s Radicalism', in Verney and Sartain (eds), Long Is the Way and Hard, pp. 75-85, p. 79.

90 CU, Viola Wertheim Bernard Papers, 1918-2000, Box 342, Folder 5.5, Carl F. Hansen to Viola Bernard, 8 April 1959.

91 CU, Viola Wertheim Bernard Papers, 1918-2000, Box 338, Folder 7.2, Max Horkheimer to Dr Bernard, 7 April 1945.

92 CU, Viola Wertheim Bernard Papers, 1918-2000, Box 338, Folder 8.2, Edwin J. Luckas to Dr Viola Bernard, 28 July 1960.

93 CU, Viola Wertheim Bernard Papers, 1918-2000: Box 338, Folder 17.1, New York Times, 11 January 1960, news clipping; also Box 338, Folder 17.1, Viola Bernard to Dr Anthony Votos, 15 September 1960.

94 CU, Viola Wertheim Bernard Papers, 1918-2000, Box 338, Folder 17.1, Dr Anthony Votos to Dr Bernard, 11 January 1960.

95 CU, Viola Wertheim Bernard Papers, 1918-2000, Box 342, Folder 1.2, Bluma Swerdloff to Viola Bernard, 13 June 1946.

96 CU, Viola Wertheim Bernard Papers, 1918-2000, Box 342, Folder 1.2, Bluma Swerdloff to Viola Bernard, 13 June 1946.

97 CU, Viola Wertheim Bernard Papers, 1918-2000, Box 342, Folder 1.2, Bluma Swerdloff to Viola Bernard, 13 June 1946.

98 Cheryl Lynn Greenberg, Troubling the Waters: Black-Jewish Relations in the American Century (Princeton: Princeton University Press, 2006), pp. 163, 169, $197,203$. 